\title{
Seasonal variations of diet composition in farmland field mice Apodemus spp. and bank voles Clethrionomys glareolus
}

\author{
Kai F. ABT** and Walter F. BOCK
}

\begin{abstract}
Abt K. F. and Bock W. F. 1998. Seasonal variations of diet composition in farmland field mice Apodemus spp. and bank voles Clethrionomys glareolus. Acta Theriologica 43: $379-389$

Feeding habits of field mice Apodemus flavicollis Melchior, 1834 and A. sylvaticus Linnaeus, 1758, and bank voles Clethrionomys glareolus Schreber, 1780 in a mixed farmland area in Northern Germany were investigated from March to December 1992. For semi-quantitative analysis of diet composition, faeces were sampled in the margins of an arable field surrounded by hedgerows. Diets of both Apodemus-species were similar, with A. flavicollis tending to eat more animal food and less green plant matter. Except in the early summer, $C$. glareolus consumed less animal matter than both Apodemus-species, but not consistently more green plant matter than A. sylvaticus. Beech flowers were important food for all species in May, whereafter rye grain became the dominant food item until August. In the autumn and winter, field mice took beechmast and acorns, while bank voles ate berries and fungi, and in December, large amounts of grass leaves. Dietary overlap was, altogether, highest from May to August (about 0.8 ). Overlap between A. flavicollis and A. sylvaticus dropped moderately after the summer, while that between $C$. glareolus and either Apodemus-species decreased sharply to levels of 0.2 and lower. Increased probability of competitive interaction between the species in the autumn and winter, corresponding to a more patchy distribution of food resources than in the summer, is discussed as a possible reason for the observed divergence of food habits.

Ökologie-Zentrum, Christian-Albrechts-Universität zu Kiel, Olshausenstraße 40, D24118 Kiel, Germany

Key words: Apodemus flavicollis, Apodemus sylvaticus, Clethrionomys glareolus, food habits, dietary overlap, farmland
\end{abstract}

\section{Introduction}

Food requirements and feeding habits of field mice Apodemus flavicollis Melchior, 1834 and A. sylvaticus Linnaeus, 1758 and bank voles Clethrionomys glareolus Schreber, 1780 have been studied extensively in the past decades and reviewed comprehensively by Hansson (1985). Both Apodemus-species may be characterized as typical granivores, feeding mainly on easily digestible, low-cellulose matter, and closely resembling each other with respect to diet composition

*Present address: Forschungs- und Technologiezentrum Westküste, Hafentörn, D-25761 Büsum, Germany 
(Hansson 1971, 1985). Proportions of primary food items, ie seeds, invertebrates and green plant matter, tend to be similar in different habitats (Hansson 1985), though considerable deviations from the regular pattern may occur (Obrtel and Holišova 1979, 1980; Rogers and Gorman 1995). The bank vole holds an intermediate position between granivores and typical herbivores, such as Microtus, depending less on high-energy food than Apodemus, and consuming more green vegetables instead (Hansson 1985). The diet of $C$. glareolus seems to be more variable with season and habitat than that of Apodemus (Hansson 1985).

Gaps in current knowledge refer mainly to the lack of information from non-woodland habitats. However, farmland environments are also colonized by woodland rodents (Pelikán and Nesvadbodá 1979, Zhang and Usher 1991), and in many areas they constitute the primary habitat of A. sylvaticus (eg Heinrich 1951, Zejda 1965, Alcántara and Tellería 1991). In Northern Germany, A. flavicollis, A. sylvaticus and C. glareolus are found in hedgerows ("Knicks") within arable land and grassland all year round, together representing the bulk of the small mammal biomass (W. Bock, pers. obs.). The present study investigates the feeding habits of these rodent species in mixed farmland with special consideration of seasonal changes.

A method uncommon in studies of small mammal food habits was employed by evaluating faecal samples, which were obtained from animals caught during a capture-mark-recapture program in 1992.

\section{Material and methods}

\section{Study area}

The study was carried out in a mixed farmland area in northern Germany near Kiel. Samples were taken along the margins of a field 2.7 ha in size surrounded by spruce-oak forest, grassland, and a maize field. Hedgerows bordered the field on all edges except the eastern. The field was initially tilled with winter-rye, which was harvested on July 29th. Subsequently, the grass Lolium perenne was sown and cut for the first time on October 30th. Large beech- Fagus sylvatica and oak-trees Quercus robur within the hedges and on the eastern edge of the field had a peak fruit-fall in the autumn of 1992 , as had the nearby beech forest.

\section{Sampling}

Faecal samples from live-trapped rodents were utilized for diet analysis in order to avoid effects on population dynamics, as well as for ethical reasons. Forty-nine Longworth-traps were set in line around the field in $15 \mathrm{~m}$ intervals. From March to December of 1992, trapping was carried out twice every month on 2 subsequent days, except when night temperatures were too low to guarantee the survival of trapped animals. Peanuts were used for baiting because their characteristic cellular pattern allowed for easy discrimination from natural food items in faecal analysis. Faecal samples were taken from the corridor of the trap only during the first capture, and corridors were cleaned after each trapping session. Samples were deep-frozen until preparation (Hansson 1970). Further details of the trapping and marking techniques applied are described in Bock (1995).

A total of 254 faecal samples were obtained from 164 specimens (Table 1). In April sampling was impossible due to cold night temperatures. 
Table 1. Numbers of faecal samples/numbers of specimens, by species and month; note that the total number of specimens per species is less than the sum of all months because some individuals yielded samples in more than one month.

\begin{tabular}{lcccccccccc}
\hline & Mar & May & Jun & Jul & Aug & Sep & Oct & Nov & Dec & Total \\
\hline A. flavicollis & $3 / 3$ & $5 / 5$ & $6 / 6$ & $16 / 14$ & $13 / 10$ & $10 / 10$ & $15 / 13$ & $13 / 10$ & $3 / 3$ & $84 / 52$ \\
A. sylvaticus & $7 / 7$ & $4 / 4$ & $11 / 9$ & $14 / 12$ & $12 / 10$ & $14 / 11$ & $13 / 13$ & $4 / 4$ & $4 / 4$ & $83 / 55$ \\
C. glareolus & $6 / 6$ & $7 / 7$ & $13 / 10$ & $12 / 8$ & $15 / 13$ & $15 / 14$ & $5 / 5$ & $11 / 10$ & $3 / 3$ & $87 / 57$ \\
Total & $16 / 16$ & $16 / 16$ & \multirow{2}{*}{$30 / 25$} & $42 / 34$ & $40 / 33$ & $39 / 35$ & $33 / 31$ & $28 / 24$ & $10 / 10$ & $254 / 164$ \\
\hline
\end{tabular}

\section{Preparation of samples}

Individual samples were put in $100 \mathrm{ml}$ glasses and suspended in $30-60 \mathrm{ml}$ water. In order to clean the undigested food particles, $2-3 \mathrm{ml} 0.5 \mathrm{M} \mathrm{NaOH}$ and 2-3 ml DOMESTOS ${ }^{\circledR}$ (ingredients: $\mathrm{NaOH}$, tensids and bleaching agents) were added, and the sample was heated for 10-20 minutes with constant stirring, until both suspension and clearing were sufficient. Amounts of water and agents, as well as duration of heating, were not critical and varied according to the size and composition of the sample. The suspension was poured through a $0.2 \mathrm{~mm}$ sieve and the wet weight of the residue measured to the nearest $0.01 \mathrm{~g}$. The sample - from large ones only a subsample - was then mounted in glycerine-gelatine, using $76 \times 26 \mathrm{~mm}$ slides and $26 \times 21 \mathrm{~mm}$ cover glasses. Slides were sealed with nail polish after 2 days, when the water content of the mounts had decreased through evaporation.

\section{Diet analysis}

Food remains were identified under 10-100-fold magnification, using histological and morphological criteria by means of a reference collection (eg Watts 1968, Hansson 1970, Butet 1985). Food items were identified to species level where possible and assigned to one of the following categories: (0) bait, (1) cereals, (2) tree seeds, (3) other seeds and fruits, (4) flowers, (5) green plant matter, (6) all remaining or non-identified plant matter, and (7) animal matter.

Realizing the extreme difficulties in establishing precise volume or weight percentages of food items by means of faecal samples, a semi-quantitative assessment of food composition was made. The relative proportion of each food item in an individual sample was subjectively estimated on the basis of 5 classes: Items making up less than $5 \%$ were only noted as present, ie given a value of 0 . An estimated proportion between 5 and $25 \%$ was assigned a value of $12.5 \%$. The three subsequent classes, each covering a range of $25 \%$, are represented by their respective class means, that is $37.5 \%$ $(25-50 \%), 62.5 \%(50-75 \%)$, and $87.5 \%(75-100 \%)$. These figures do not necessarily sum up to $100 \%$ in an individual sample, eg when there was only one item $(87.5 \%)$, or when bait had been consumed. The proportion of the latter was excluded from subsequent calculations.

\section{Data analysis}

For reasons related to the different retention times of various kinds of food in the alimentary tract, true proportions of food items were assumed to be better represented in large faecal samples than in small ones (Hansson 1970). This is considered especially important in the case of a heterogenous diet composition (Abt 1991), as in the species under study. The volume percentage index V of a given food category $i$ was therefore calculated as: 


$$
\mathrm{V}_{(\mathrm{x}) i j}=\frac{\sum_{k=1}^{n} \mathrm{P}_{(\mathrm{x}) i j k} \mathrm{~W}_{(\mathrm{x}) j k}}{\sum_{i} \sum_{k=1}^{n} \mathrm{P}_{(\mathrm{x}) i j k} \mathrm{~W}_{(\mathrm{x}) j k}}
$$

where $n$ is the number of faecal samples of species $\mathrm{x}$ in month $j, \mathrm{P}(\mathrm{x}) \mathrm{ijk}$ is the volume percentare class assigned to the $i$ th food category in the $k$ th sample, and $\mathrm{W}_{j k}$ is the weighing factor of that samplederived from the wet weight of the processed sample.

Weighting by some measure of sample mass is considered to eliminate part of the bias associated with faecal samples. However, volume percentages given in the present paper are not entirely comparable to those in previous studies, most of which are cited in Hansson (1985). Apart fiom the inherent difficulties in estimating relative volumes of diet items from undigestible food remans, the feeding behaviour of the animals caused additional problems. According to observations at feeding sites, grain-eating rodents tended to discard the analytically relevant outer parts of the caryopse at least in the late summer, which probably caused severe underestimation of the proportion of sereals.

The similarity between the diet compositions of 2 species within one month was expresset by an index derived from probability theory (Horn 1966), commonly used in comparisons of feeding habits (eg Zaret and Rand 1971, Holišova and Obrtel 1980):

$$
\mathrm{C}_{(\mathrm{xy}) j}=\frac{2 \sum_{i \neq 1} \mathrm{~V}_{(\mathbf{x}) i j} \mathrm{~V}_{(\mathbf{y}) i j}}{\sum_{i} \mathrm{~V}_{(\mathbf{x}) i j}^{2}+\sum_{i} \mathrm{~V}_{(\mathbf{y}) i j}^{2}}
$$

with $\mathrm{C}_{(\mathrm{xy}) j}$ indicating dietary overlap between species $\mathrm{x}$ and $\mathrm{y}$ in month $j$. $\mathrm{V}_{(\mathrm{x}) i j}$ and $\mathrm{V}_{(\mathrm{y}) i j}$ are the respective volume proportion indices of diet category $i$ in those species. C ranges from 0 (no overlap in diet composition) to 1 (identical diet compositions). Note that among the 7 diet categories, No. 6 (various or unidentified plant matter) is excluded from the numerator sum, ie treated as if always representing different food items in species $\mathrm{x}$ and $\mathrm{y}$, which may not be entirely true.

The probability distribution of $\mathrm{C}_{(\mathrm{xy}) j}$ was established by means of the following botstrap procedure (Sokal and Rohlf 1995): All individual samples of species $\mathrm{x}$ and $\mathrm{y}$ in month $j$ were considered as one sample of size $\left[n_{(\mathrm{x}) j}+n_{(\mathrm{y}) j}\right]$. From this original sample, pseudo-samplts were generated by randomly selecting and combining $\left[n_{(\mathbf{x}) j}+n_{(\mathbf{y}) j]}\right]$ individual samples, disregarding the original figures of $n_{(\mathrm{x}) j}$ and $n_{(\mathrm{y}) j}$. Pseudo-values of $\mathrm{C}_{(\mathrm{xy}) j}$ were calculated via pseudo-values of $\mathrm{V}_{\mathrm{x}) i j}$ and $\mathrm{V}_{(\mathrm{y}) i j}$ from each of those pseudo-samples. For every $\left.\mathrm{C}_{(\mathrm{xy})}\right)$, a number of 500 pseudo-sampls were created. The latter occasionally contained individual samples of only one of the 2 species, so that no pseudo-value of $\mathrm{C}_{(x y) j}$ could be calculated. However, the number of such pseudo-samples never exceeded 20. Upper and lower 95\%-confidence limits of $\mathrm{C}_{(\mathrm{xy}) j}$ were determined as the $97.5 \%$ - and $2.5 \%$-percentiles of pseudo-value distributions, respectively.

\section{Results}

Cereals, namely rye, served as the main food for all three species in the seriod of June-August, and for A. sylvaticus up to September (Fig. 1). Some rye wis still eaten thereafter, presumably originating from caches set up by the animals curing the summer. In A. sylvaticus and A. flavicollis, some cereal matter (maizs) was also found in March, probably taken from the remainder of the preceeding year's crop in neighbouring fields. 
Tree seeds were of some importance in Apodemus diet in spring, but almost disappeared during the summer. In the autumn and winter, acorns and/or beechmast (which are hard to distinguish in faecal samples) became more and more important (Fig. 1), apparently compensating for the decline in cereal availability. In $C$. glareolus, on the other hand, tree seeds made up only a neglegible part of the diet throughout the year.

A variety of other seeds, fruits and caryopses were identified. However, food sources lumped in this category were important only in C. glareolus, especially in the autumn with fruit and seed of Sambucus nigra. Eventually, there was also a moderate peak in the proportion of weed seeds and caryopses (Poa spec.) in A. sylvaticus in June (Fig. 1). Interestingly, seeds of Brassicaceae and Chenopodiaceae and caryopses of Digitaria spec. were, with one single exception, found only in Apodemus samples. As these weeds are typical elements of the field flora,

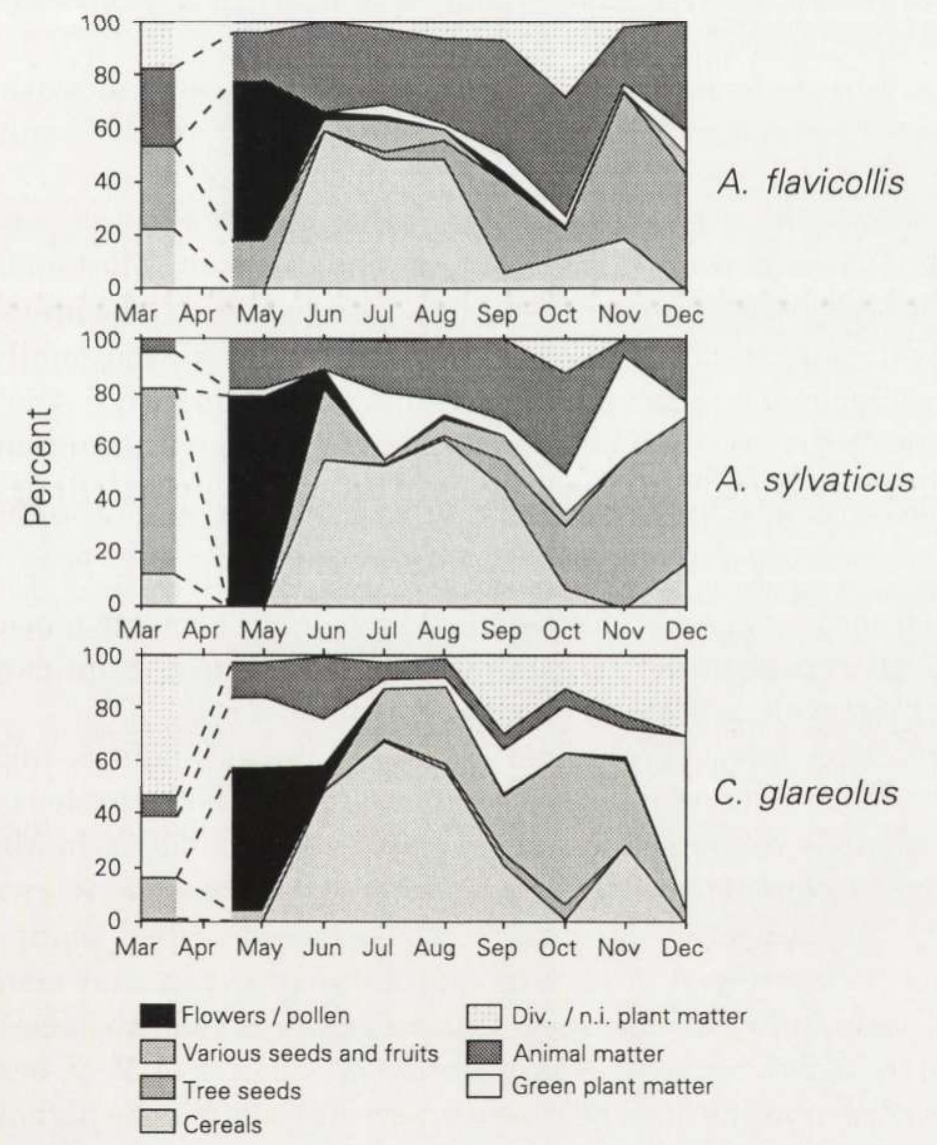

Fig. 1. Seasonal variations in the diet composition of rodents Apodemus flavicollis, Apodemus sylvaticus and Clethrionomys glareolus in a Northern German mixed farmland area in 1992; n.i. non-identified. 
their absence in C. glareolus samples may indicate the restriction of this species to the immediate vicinity of the hedgerows, whereas A. flavicollis and A. sylvaticus both ranged farther into the field area.

Ingested parts of flowers of both mono- and dicotyledons were mostly anthers, indicating that the matter of interest to the animals was pollen. Flowers usually occured only in small amounts, but reached extraordinarily high proportions in May (Fig. 1). By this time, beech flowers covered much of the ground along the hedgerows as well as in the nearby beech forest. The anthers were found in considerable amounts in all samples of that month, except for some C. glareolus.

Green plant matter was most important in the diet of $C$. glareolus, with a decline in July and August and a significant rise in December (Fig. 1), when grass leaves (Lolium perenne) made up the biggest part of the diet. The general importance of this category in A. sylvaticus appeared not much lower than in $C$. glareolus, but peaks occurred in July and November. In A. flavicollis V-values of green vegetables never exceeded $5 \%$.

The proportion of animal matter remained relatively constant with season (Fig. 1). This category was most important in A. flavicollis, with V-values of about $20-40 \%$ throughout the year. As with other food items, A. sylvaticus tended to resemble $A$. flavicollis rather than $C$. glareolus in this respect, whereas in the latter species V-values were considerably lower, except in May and June. Some insect taxa, namely caterpillars (Noctuidae) and beetles (Coleoptera), seemed to be available all year round, while other prey occurred more seasonally. The occurrence of Tipulidae matches the prevalence of grass on the field in the autumn and winter. Earthworms (Lumbricidae) were primarily eaten in the summer. Note that the importance of animal food may be over-estimated due to limitations of the method.

Miscellaneous, partly non-identifiable plant matter (fungi, bark, roots a. o.) was found in all species, with A. flavicollis and A. sylvaticus showing a peak in October (Fig. 1). In C. glareolus, such food, mainly fungi, made up a significant part of the diet in March, as well as from September to December.

Large confidence intervals of dietary overlap values $\mathrm{C}$ indicate high variability in the composition of individual faecal samples in one or both species in that month (Fig. 2), occasionally reinforced by small sample sizes (Table 1). In March, overlap of the diet of C. glareolus with that of either Apodemus-species was very low, partly due to the utilization of miscellaneous, non-identified plant matter. The degree of overlap between A. flavicollis and A. sylvaticus in that month could not be assessed with sufficient accuracy. Confidence intervals are also large in the comparisons of $C$. glareolus with either Apodemus-species in May, because of high individual variation in the former. However, overlap tends to be high in both cases. A. flavicollis and A. sylvaticus showed a marked overlap in May due to the dominance of beech flowers in their diet. In the period of June-August, diet compositions of all species were quite similar, all being dominated by rye grains. 


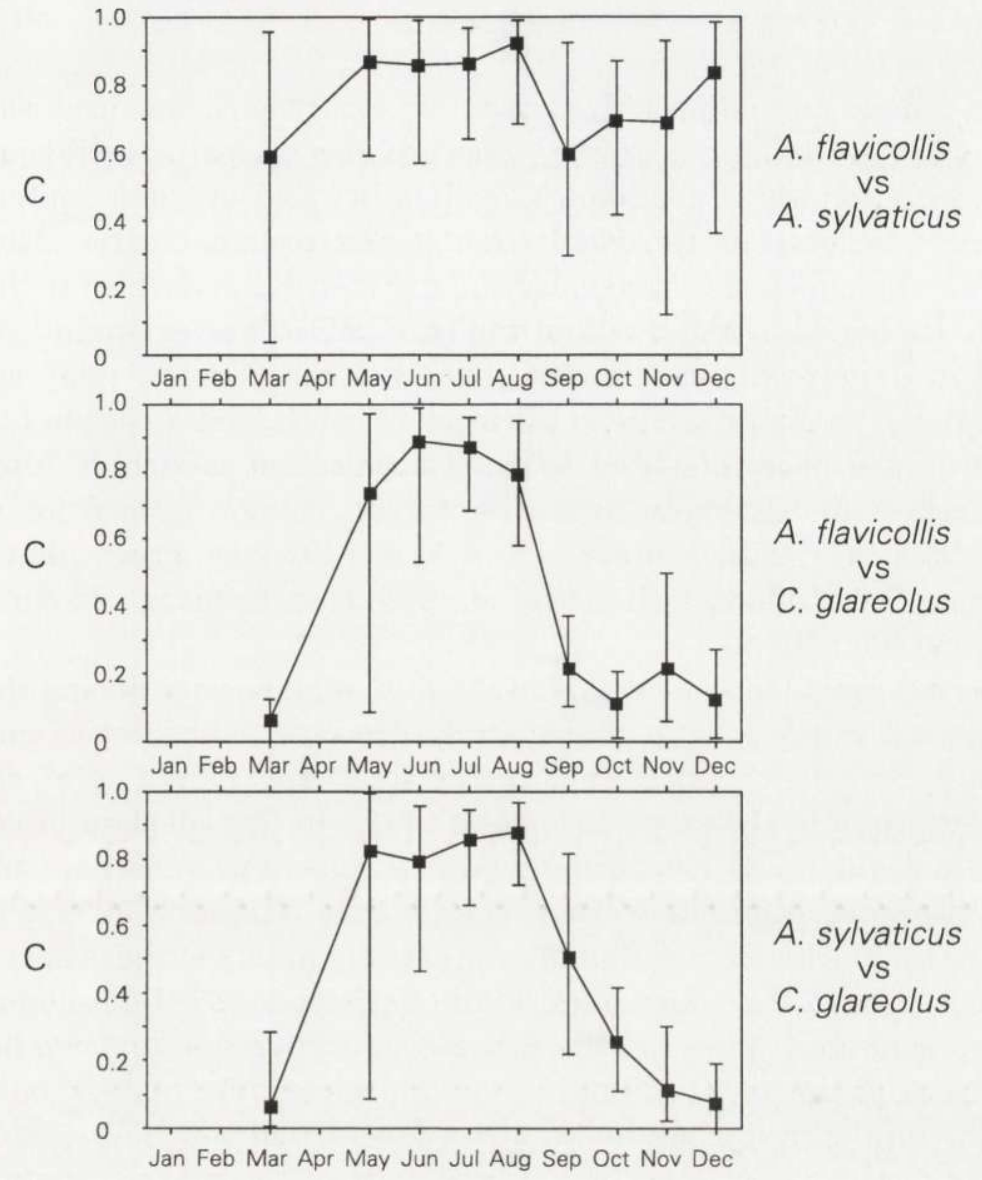

Fig. 2. Seasonal variations of dietary overlap C between rodent species; bars denote $95 \%$-confidence intervals.

Similarity dropped thereafter, most sharply between A. flavicollis and C. glareolus. Overlap between $A$. flavicollis and A. sylvaticus remained above 0.5 throughout the rest of the year, though with increased variance, while that of $C$. glareolus with either Apodemus-species fell below 0.2 in the winter. The moderate but significant drop of overlap between A. flavicollis and A. sylvaticus in the autumn arose from (1) the persistence of rye in the diet of $A$. sylvaticus until September in contrast to A. flavicollis and (2) the more intense utilization of green plant matter, namely grass leaves, by the former species. The marked divergence of $C$. glareolus food habits from those of Apodemus spp. in the autumn and winter reflects the primary consumption of berries, grass leaves, and other plant matter such as fungi and bark, while tree seeds and animal matter were scarcely taken. 


\section{Discussion}

The most prominent finding of the present investigation is the mass consumption of beech flowers by all species in May. Beech pollen appeared as favourable food for rodents with respect to abundance, availability and nutrient content, though the latter may be only partly usable due to the resistent exine. However, no previous report on pollen as a (temporary) major food item is known to the authors. This may be explained by the fact that the only published year-round study on $A$. flavicollis and C. glareolus food habits in beech forest (Drożdż 1966) covered the spring period of a year with poor fructification of beech, and accordingly few beech flowers must have been available. When fructification is rich or intermediate, however, beech pollen is likely to provide important spring food for rodents in conforming habitats. Animal matter - in C. glareolus also green plant matter otherwise compensates for the shortness of (seed) food in spring and early summer (Hansson 1985, Pelz 1989).

The observed prevalence of cereals in the diet of all species during the summer may be expected in the habitat under study. However, substantial consumption of cereals has previously not been reported in A. flavicollis and C. glareolus, except for an earlier study in the same area (Abt 1991). In fact, disdain of cereals and grass seeds in A. flavicollis has formerly been discussed as a mechanism contributing to the ecological seperation from A. sylvaticus (Heinrich 1951, Pfeiffer and Niethammer 1972). However, differences in feeding habits of these species, if any, seem at most to be of the behavioural kind (Hoffmeyer 1976). It should be noted that rye was available to the rodents without limitation due to down-bent blades in many places of the field. Animals were therefore able to seek out this food source with a minimum probability of direct interaction with individuals of other species. This might be an important prerequisite of the marked dietary overlap between species throughout the summer, as frequent interaction is likely to promote ecological segregation (eg Hoffmeyer 1973, Abramsky 1981).

Cereals eaten in the autumn were probably stored by the animals in July, ie prior to harvesting and ploughing. In previous studies, no caching of seeds was observed in C. glareolus and A. sylvaticus until autumn (Miller 1955, Ashby 1967). It is suggested that storing activity is, at least to some extent, related to food abundance rather than directly to season.

In both Apodemus-species, the drop in the abundance of rye following harvest was compensated by shifting towards tree seeds (acorns and beechmast) in the autumn and winter. Surprisingly, this did not happen in C. glareolus, which species turned towards other foods instead, although tree seeds are appropriate food for C. glareolus (Hansson 1985), and appeared to be available in surplus. The distribution of this food source along the hedgerows was, however, more patchy than that of rye. A possible explanation might be that agonistic dominance of Apodemus in the tree seed foraging sites restricted $C$. glareolus to other food 
sources. Alternatively, habitat preferences of $C$. glareolus may have been the cause, rather than interaction with Apodemus. From the available data, it is not possible to decide whether competitive interaction between $C$. glareolus and Apodemus produced the observed divergence of food habits, though this appears reasonable.

Trophic requirements of $A$. flavicollis and A. sylvaticus are so similar that broad dietary overlap may occur in any case of their coexistence, even in habitats of low productivity (Holišova and Obrtel 1980). Competitive interaction between them has been confirmed both experimentally (Hoffmeyer 1973) and in field studies (Hoffmeyer and Hansson 1974, Montgomery 1980). It is likely that the marked overlap in resource utilization in the spring and summer was possible only through small-scale spatial segregation of the species (Montgomery 1979, 1980), facilitated by the super-abundance and diffusive distribution of (cereal) food. Moreover, A. sylvaticus tended to colonize the field area in the summer, whereas A. flavicollis did not settle outside the hedgerows (W. Bock, in prep.). The drop of dietary overlap in the autumn may therefore be a consequence of a more patchy distribution of seed food, if not a general decrease in food availability, which enhanced the probability of competitive interaction.

In the more original (woodland) habitats of field mice and bank voles, summer has been recognized as a period of relative food shortage due to a bottle-neck in seed abundance (Hansson 1971, Obrtel and Holišova 1976). In contrast, food availability was at a maximum in that season in the present study. Rodents inhabiting hedgerows or woodland adjacent to corn fields benefit from the crop through improved recruitment in summer (W. Bock, in prep.). If there is no direct access to the crop, animals tend to use hedgerows as pathways between residence and feeding site (Abt 1991, Zhang and Usher 1991), and may thus overcome distances of several 100 m (Holišova and Obrtel 1980, Babińska-Werka 1990, Abt 1991).

In accord with Zhang and Usher (1991), it appears that hedgerows between arable fields constitute fairly suitable habitats for small mammals, even for typical woodland rodents such as A. flavicollis and $C$. glareolus. However, the extreme temporal and spatial variations of food abundance in modern farmland are likely to provide a severe challenge to small rodents. Apart from caching, high mobility, at least in the typical granivores, provides a means to deal with these changes. The partially herbivorous character of Clethrionomys, on the other hand, may rather enable this species to switch to poorer foods when utilized field crops are removed abruptly.

Acknowledgements: This study was carried out with financial support of the Federal Ministry of Research and Technology of Germany (BMFT) as part of the ecosystem research project "Bornhöveder Seenkette". Prof H. Bohlken and Prof E. Haase kindly provided space and equipment for laboratory work at the Institute of Domestic Animal Research of Kiel University. Prof S. Halle, Dr G. Nehls and Dr S. Efthimiou gave helpful comments on earlier versions of the MS. We thank all of them. 


\section{References}

Abramsky Z. 1981. Habitat selection and competition in two Mediterranean Apodemus spp. Oikos 36: $219-225$,

Abt K. F. 1991. Zur Kenntnis der Sommernahrung von Wald- und Gelbhalsmaus im Gebiet der Bornhöveder Seenkette. Thesis, University of Kiel, Kiel: 1-74.

Alcántara M. and Tellería J. L. 1991. Habitat selection of the wood mouse (Apodemus sylvaticus) in cereal steppes of central Spain. Zeitschrift für Säugetierkunde 56: 347-351.

Ashby K. R. 1967. Studies on the ecology of field mice and voles (Apodemus sylvaticus, Clethrionomys glareolus and Microtus agrestis) in Houghall Wood, Durham. Journal of Zoology, London 152: 389-513.

Babińska-Werka J. 1990. Response of rodents to an increased and quantitatively diverse food base. Acta Theriologica 35: 151-156.

Bock W. F. 1995. Kleinsäugerforschung im Ökosystemforschungsprojekt "Bornhöveder Seenkette" Interdisziplinäre Zusammenarbeit und Methoden. Methoden feldökologischer Säugetierforschung 1: $311-320$.

Butet A. 1985. Méthode détude du régime alimentaire dún rongeur polyphage (Apodemus sylvaticus L., 1758) par lanalyse microscopique de fces. Mammalia 49: 455-483.

Drożdż A. 1966. Food habits and food supply of rodents in the beech forest. Acta Theriologica 11: 363-384.

Hansson L. 1970. Methods of morphological diet micro-analysis in rodents. Oikos 21: 255-266.

Hansson L. 1971. Small rodent food, feeding and population dynamics. Oikos 22: 183-198.

Hansson L. 1985. The food of bank voles, wood mice and yellow-necked mice. Symposia of the Zoological Society of London 55: 141-168.

Heinrich G. 1951. Die deutschen Waldmäuse. Zoologisches Jahrbuch, Abteilung Systematik, Ökologie und Geographie der Tiere 80: 99-122.

Hoffmeyer I. 1973. Interaction and habitat selection by the mice Apodemus flavicollis and A. sylvaticus, Oikos 24: 108-116.

Hoffmeyer I. 1976. Experiments on the selection of food and foraging site by the mice Apodemus sylvaticus (Linne, 1758) and A. flavicollis (Melchior, 1834). Säugetierkundliche Mitteilungen 24: $112-124$.

Hoffmeyer I. and Hansson L. 1974. Variability in number and distribution of Apodemus flavicollis (Melch.) and A. sylvaticus (L.) in South Sweden. Zeitschrift für Säugetierkunde 39: 15-23.

Holišova V. and Obrtel R. 1980. Food resource partitioning among four myomorph rodent populations coexisting in a spruce forest. Folia Zoologica 29: 193-207.

Horn H. S. 1966. Measurement of "overlap" in comparative ecological studies. The American Naturalist 100: 419-424.

Miller R. S. 1955. Activity rhythms in the wood mouse Apodemus sylvaticus and the bank vole Clethrionomys glareolus. Proceedings of the Zoological Society of London 125: 505-519.

Montgomery W. I. 1979. Trap-revealed home range in sympatric populations of Apodemus sylvaticus and A. flavicollis. Journal of Zoology, London 189: 535-540.

Montgomery W. I. 1980. Spatial organization in sympatric populations of Apodemus sylvaticus and A. flavicollis (Rodentia: Muridae). Journal of Zoology, London 192: 379-401.

Obrtel R. and Holišova V. 1976. Trophic diversity and dietary overlap of two sympatric rodents. Zoologické Listy 25: 217-227.

Obrtel R. and Holišova V. 1979. The food eaten by Apodemus sylvaticus in a spruce monoculture. Folia Zoologica 28: 299-310.

Obrtel R. and Holišova V. 1980. The food eaten by Apodemus flavicollis in a spruce monoculture. Folia Zoologica 29: 21-32.

Pelikán J. and Nesvadbová J. 1979. Small mammal communities in farms and surrounding fields. Folia Zoologica 28: 209-217. 
Pelz H.-J. 1989. Ecological aspects of damage to sugar beet seeds by Apodemus sylvaticus. [In: Mammals as Pests. R. S. Putman, ed]. Chapman \& Hall, London, New York: 34-48.

Pfeiffer H. and Niethammer J. 1972. Versuche zur Nahrungswahl von Wald- und Gelbhalsmäusen (Apodemus sylvaticus und A. flavicollis). Zeitschrift für Säugetierkunde 37: 57-65.

Rogers L. M. and Gorman M. L. 1995. The diet of the wood mouse Apodemus sylvaticus on set-aside land. Journal of Zoology, London 235: 77-83.

Sokal R. R. and Rohlf F. J. 1995. Biometry. 3rd edition. Freeman and Company, New York: 1-887.

Watts C. H. S. 1968. The foods eaten by wood mice (Apodemus sylvaticus) and bank voles (Clethrionomys glareolus) in Wytham Woods, Berkshire. Journal of Animal Ecology 37: 25-42.

Zaret T. M. and Rand A. S. 1971. Competition in tropical stream fishes: support for the competitive exclusion principle. Ecology 52: 336-342.

Zejda J. 1965. Habitat of the long-tailed field mouse (Apodemus sylvaticus L.) in the lowland region. Zoologické Listy 14: 301-316.

Zhang Z. and Usher B. 1991. Dispersal of wood mice and bank voles in an agricultural landscape. Acta Theriologica 36: 239-245.

Received 22 July 1997, accepted 11 August 1998. 